\title{
Children and Cheap Print from a Transnational Perspective ${ }^{1}$
}

\author{
Laura Carnelos \\ Library Curator of Rare Books and Manuscripts, Eton College Library, Windsor, United \\ Kingdom
}

\section{Elisa Marazzi}

Marie Skłodowska Curie Research Associate, Newcastle University, United Kingdom

\begin{abstract}
From their earliest existence cheap printed texts were intended to be read by a mixed-age audience, young people included. Research on children's literature has flourished in the last decades, nonetheless the role that cheap and ephemeral print played in early modern children's lives has been largely overlooked.

Based on both existing literature and new research in various European areas, this article asks how, where, and when a market for a distinctively children's cheap print took shape and how transnational this phenomenon was. It demonstrates that children were avid consumers of cheap print even before they were openly addressed to in titlepages and paratexts, and that a market for them developed at different paces in early modern European countries. In some areas, books for children were produced even before the so-called birth of modern children's literature. Furthermore, this essays shows how the evolution of printing techniques and especially the introduction of colour changed this market, making a wider range of printed products more widely affordable by juvenile audiences as well as more appealing to young eyes.
\end{abstract}

\section{Keywords}

Children's books - schoolbooks - colour printing techniques - popular books - transnational studies

\section{Introduction}

It is surely beyond doubt that cheap printed texts were, from their earliest existence, intended to be read by a mixed-age audience, young people included. Irrespective of any changes to the conceptualisation of childhood in early modern European society (something still argued over by historians), some texts were explicitly directed at learners, such as school books, but also much that wasn't specifically intended for young readers was indeed consumed by

\footnotetext{
${ }^{1}$ This essay is the result of a group collaboration. Laura Carnelos edited the first part on didactic publications, while Elisa Marazzi edited the second part on pleasant readings. We wrote together the introduction and conclusions. We are extremely grateful to the working group comprising Miriam Borham Puyal, Emmanuelle Chapron, Matthew Grenby and Francesca Tancini. We also thank Charlotte Appel, Sofie Arneberg, Helwi Blom, Nina Christensen, Hans-Heino Ewers, Andrea van Leerdam and Feike Dietz, and Sara Segura Arnedo for providing information and feedback. A special thanks to Matthew Grenby and Jeroen Salman for their generous comments and suggestions. Any mistakes remain our own responsibility All links were last accessed on $11 / 10 / 2020$
} 
them. ${ }^{2}$ Categorial evidence of this dual address can be difficult to find. An early example is a Dutch illustrated 'book of secrets' printed in 1528, Den sack der consten [The Bag of Arts]. It was described in its prologue as containing 'Som wat sots voor die ionghers ende som anders' ('some silly things for the youngsters and some other things'), suggesting that the book was intended for the entire family or household. ${ }^{3}$ By the end of the eighteenth century, more or less across all of Europe, things had changed: a separate market for young people had been created.

The role that cheap and ephemeral print played in early modern children's lives has been largely overlooked by research on both popular print and children's books - a regrettable omission considering the pervasive presence of popular print in early modern society. ${ }^{4}$ This article asks how, where, and when a market for a distinctively children's cheap print took shape and how transnational this phenomenon was. Further, it demonstrates that, before the so-called birth of modern children's literature in the eighteenth century, a small amount of cheaply printed products was already being published with a juvenile audience in mind.

Since so little work has been undertaken on children's cheap print, particularly from a transnational perspective, the basis for this paper has been a newly commissioned survey, launched in 2017, assessing what is known about young people's use of cheap print countryby-country. The survey involved scholars mainly from Western Europe (the United Kingdom, the Netherlands, Germany, France, Spain, Italy, and Scandinavian countries), including areas often neglected in trans-European studies such as Norway and Denmark. Although research on cheap print in Scandinavian countries is still at an early stage, ${ }^{5}$ the extensive digitisation carried out by their National Libraries significantly facilitates comparative and transnational analysis. As far as Germany is concerned, book history and the history of children's literature are so far still separate fields, making this area more difficult to compare with other countries. Since predictable similarities between neighbouring countries have emerged, we have adopted a division between Northern (the United Kingdom, the Netherlands, Norway, Denmark, Scandinavian countries) and Mediterranean countries (France, Spain, Italy) which is purely functional for this survey.

\footnotetext{
${ }^{2}$ S. Lerer, Children's Literature. A Reading History from Aesop to Harry Potter (Chicago and London 2008), p. 1.

${ }^{3}$ Translation by Andrea van Leerdam. A facsimile of the 1528 edition is available in Den Sack der Consten: en Vlaams volksboek gereproduceerd naar de Antwerpse druk van Jacob van Liesvelt uit 1528 (Brugge 1989). On books of secrets see W. Eamon, Science and the Secrets of Nature. Books of Secrets in Medieval and Modern Societies (Princeton 1996). See also the special issue of Nuncius: 'Printing Medical Knowledge: Genres, Reception and Dissemination', ed. S. Minuzzi, forthcoming.

${ }^{4}$ Only isolated attempts have been made to investigate children's popular print, and only within individual national contexts (or even in specific cities): J. Salman, 'Children's books as a commodity: the rise of a new literary subsystem in the eighteenth-century Dutch republic', in: Poetics, 28 (2001), n. 5-6, pp. 399-421; M.O. Grenby, 'Before Children's Literature: Children, Chapbooks and Popular Culture in Early Modern Britain', in: Popular Children's Literature in Britain, ed. J. Briggs \& D. Butts (Burlington 2008), pp. 25-46; J. Cooper, 'The Development of the Children's Chapbook in London', in: Street Literature of the Long Nineteenth Century. Producers, Sellers, Consumers, ed. D. Atkinson \& S. Roud (Newcastle upon Tyne 2017), pp. 217-40; V. Bold, “"Entertaining and Instructing Histories": Children's Chapbook Literature in the Nineteenth Century', in: The Land of Story Books. Scottish Children's Literature in the Long Nineteenth Century, ed. S. Dunnigan \& S.-F. Lai (Glasgow 2019), pp. 42-62.

${ }^{5}$ On popular print in Danmark see H. Horstbøll, Menigmands medie. Det folkelige bogtryk i Danmark 15001840 (Copenhagen 1999). More recently, two projects on children's literature in Denmark and Norway take in account cheap material: C. Appel \& N. Christensen, 'Follow the Child, Follow the Books. Cross-Disciplinary Approaches to a Child-Centred History of Danish Children's Literature 1790-1850', in: International Research in Children's Literature, 10 (2017), n. 1, pp. 194-212 and the project Literary Citizens of the World: https://www.nb.no/en/forskning/literary-citizens-of-the-world-litcit/.
} 
As some of the categories we use are problematic, it is worthwhile mentioning that with the words 'children' and 'childhood' we pragmatically refer both to infants, children and young adults. By 'cheap print' we mean those publications poorly printed and widely distributed as described in the first articles of this special issue ${ }^{6}$ with the awareness that, in the nineteenth century, this term assumed a slightly different nuance due to the changes in printing techniques and an increasing purchasing power of consumers.

For pragmatic reasons, we have divided the books enjoyed by children into two broad categories. On the one hand we have educational publications, that were evidently used by young people in educational contexts, at home or at school, including ABCs, primers, catechisms and texts teaching various skills or modes of conduct. On the other hand, we have recreational books, represented by illustrated broadsides, chapbooks containing romances, songs, poems, moral tales and so on, usually read for pleasure. As we will see, there are many overlaps between these two categories, and to add further complication, actual use and intended use very often differed. Nevertheless, we have decided to retain this distinction between educational and recreational products in order to sketch the intricate pattern of encounters between popular print and young audiences better.

\section{Teaching with popular print}

Books intended for educational purposes represented a significant part of the popular print market in the majority of European areas. The range of 'educational books' was extremely wide: from primers to religious and educational stories, including exempla and 'how-to-do' manuals (e.g. how to educate children, how to confess, and other handbooks). In the Northern countries, even before education became compulsory in the ninenteenth century, an important part of this production was specifically conceived for children. ${ }^{7}$ In Mediterranean Europe on the other hand, educational cheap print was definitely used for and read by children but, unlike in Northern countries, publications addressed exclusively to children are almost untraceable before the eighteenth century. The reasons for this delay need further research. Keeping in mind that confessional differences could have led to different approaches to literacy, it is likely that in Catholic countries a teaching method essentialy based on the memorisation of religious texts, together with a late establishment of a national and free school system, slowed down the creation of a specific market for texts to support children's education. $^{8}$

In early modern Britain, the standard path for educating a child was first the 'hornbook' or some other alphabet; then the syllabary and spelling lists, perhaps included alongside a church catechism to form an 'abcie book'; and then the 'primer'. Primers came in different forms. Some could include basic pedagogic material (such as the alphabet), but the main body of these books had a dual function, combining basic literarcy tuition with liturgical material such as prayers, psalms and church services. The most famous example is the New England Primer, which developed from British versions in the late seventeenth century to become probably the most successful printed item in the American colonies. All of these forms were in use from the very earliest days of print, in the late fifteenth century, and were modified during the Reformation. In 1694, for example, the printer known as 'J.G.'

\footnotetext{
${ }^{6}$ See the articles by Carnelos, Salman, and Graheli in this volume.

${ }^{7}$ European governments started to create new policies for educating young people at the end of the eighteenth century to reinforce school attendance by means of a national and free school system. This boosted the production of didactic books. The bibliography on this topic is vast, a general reference is M.J. Maynes, Schooling in Western Europe: A Social History (Albany 1985).

${ }^{8}$ For an up-to-date discussion of the confessional implications see M. Roggero, 'Alfabetizzazione, libri e frontiere religiose. Interpretazioni da ridiscutere', in: Studi storici, 59 (2018), n. 3, pp. 667-88.
} 
could speak of the 'Swarms of Books for Children, already Printed, as Primars, Tutors, \&c.'. These books stayed in use until the eigtheenth and nineteenth centuries. The old-fashioned hornbook, for example, evolved into the 'battledore', which seems to have been a uniquely British item - a piece of card, folded into three and printed on both sides, usually featuring the alphabet, syllables, but also images and short pieces of religious or secular text. From the start of the eighteenth century, publishers began to understand the commercial potential of these texts, and a thriving market emerged for books teaching the basics of literacy, numeracy, religion, and in other fields too, but in more inventive and attractive ways, and in formats that were designed to be less ephemeral. These could be quite expensive, but there was a cheaper end of the market too - so that by 1800 , most children, both in London and the provinces, had access to cheap educational print.

In the Northern Netherlands (the Dutch Republic), already at the end of the sixteenth century, there were nursery schools intended for pre-schoolers to learn the alphabet and simple religion texts, and primary schools where children up to eight years old were taught how to read, pray, sing and sometimes count. Every town and village had such schools. ${ }^{9}$ This early education system probably stimulated the production of a great variety of books for didactic purposes from the Kleine ABC-boek [Small ABC book] to the Letterkonst [Grammar book] and the Spreuken van Salomo [Proverbs of Solomon]. Although not always specifically addressed to the young readers, primers, catechisms and secular literature were widely adopted for educational purposes in the country. In the seventeenth century, more publications were specifically addressed to young readers. For example, in the Historie van de vier vrome ridders [History of the Four Pious Knights], approved in 1619, one can read 'tot vermaek der jonkheyt toegelaten' [admissible for the amusement of youth] on the title page. ${ }^{10}$ It is interesting to note that in the Northern Netherlands children had to learn the different alphabets which were used for writing and printing. Some texts were therefore printed in two Gothic typefaces, 'civilité' and blackletter, respectively for francophones and Flemish-Dutch speakers, such as the nineteenth-century edition of De schoone historie van Joseph [The Beautiful History of Joseph] printed in Gent from the 1642 Antwerp edition. ${ }^{11}$

In a number of Northern coutries primarily in the eighteenth century, but with some exceptions from the seventeenth to the nineteenth centuries, a reading primer with the picture of a rooster on the title page or the front cover became a common textbook. Called rooster primer (Dutch: haneboek; Estonian: kukkeaabits; Finnish: aapiskukko; German: Hahnenfibel; Latvian: gaila äbece; Norwegian: hane-bog), it consisted of catechetical texts alone or with the addition of secular texts. Available in various languages, most of these primers have Protestant catechetical content (according to the geographical area this could be Lutheran or Calvinistic), but occasionally also Catholic versions were printed. ${ }^{12}$

\footnotetext{
${ }^{9}$ J. Salman, 'Education and Literacy', available at https://www.bibliopolis.nl/handboek/search/recordIdentifier/HBB\%3A2.4.2/maximumRecords/1. On Dutch schoolbooks see D. Van Miert, 'Education', in: The Cambridge Companion to the Dutch Golden Age, ed. H.J. Helmers \& G.H. Janssen (Cambridge 2018), pp. 333-49; De hele Bibelebontse berg. De geschiedenis van het kinderboek in Nederland en Vlaanderen van de Middeleeuwen tot heden, ed. N. Heimeriks \& W. van Toorn (Amsterdam 1989), in particular A. van Toorn \& M. Spies, “'Christen Jeugd, leerd Konst en Deugd”. De zeventiende eeuw', in ivi, pp. 105-67, and P.J. Buijnsters, 'Nederlandse kinderboeken uit de achttiende eeuw', in ivi, pp. 169-228.

${ }^{10}$ Available at https://books.google.co.uk/books?id=dYY-

AAAAcAAJ\&printsec=frontcover\&source=gbs_ge_summary_r\&cad=0\#v=onepage\&q\&f=false .

${ }^{11}$ Available at https://books.google.co.uk/books?id=MRxKAAAAcAAJ\&pg. See Salman, 'Education and

Literacy', art. cit. (n. 9).

${ }^{12}$ Catechism Primers in Europe, ed. B. Juska-Bacher, W. Sroka, \& T. Laine, (Bad Heilbrunn 2020)

forthcoming.
} 
In Denmark and Norway evidence of a limited number of grammars and catechisms explicitly printed for children dates back to the sixteenth century - an example is the 1574 edition of Luther's little catechism printed in Copenhagen described as suitable for 'vnge Folck och B $\varnothing$ rn' [young people and children] ${ }^{13}$ - whereas a wide range of educational books such as ABCs, primers and schoolbooks were developed, starting from the 1770s. In general, parents would be expected to buy schoolbooks for their children. However, in many schools, small sets of books were bought by the local government so that children from poor families could use them. ${ }^{14}$

In Spain the education of children was strictly connected to the rules and texts issued by the Roman Catholic Church. From the eleventh century onwards, various synods encouraged priests to teach children in parish schools how to read and, more specifically, to read the catechism. For example, 1498 Constituciones del arzobispado de Toledo stated: 'Priests or other people entrusted by priests are obliged by the synodal decrees to teach children every Sunday after vespers'. 15

With the coming of the printed book, in the last quarter of the fifteenth century, cartillas, doctrinas and catecismos started to be produced precisely for this purpose. The cartillas usually contained the alphabet, syllables, and sometimes a few basic grammar notions. These ephemeral booklets were very cheaply produced and were used in schools until they were completely worn out. A child would normally learn his/her first letters at the age of 3-5, hence the news about the future Philip II who could not yet read at 5 generated some surprise. ${ }^{16}$

Although longer than cartillas, the doctrinas were mainly produced as pliegos sueltos or cheap editions with usually 24 sheets and 48 pages. They were easily affordable. ${ }^{17}$ Most included a simplified version of the Christian doctrine, and sometimes other texts which were useful for improving one's reading skills. More extensive catechisms entitled Doctrinas cristianas were addressed to older children and adults.

It was not until the late nineteenth century that a didactic literature specifically for children developed in Spain. Under the influence of first the Enlightenment and then Romanticism, this new children's literature took the shape of moral story collections. The use of diminutive for names in titles was common, for instance 'Juanito', meaning 'young Juan': an interesting market strategy that probably gives an indication of audience. Generally, these titles brim with a conservative and middle-class sensibility. ${ }^{18}$ Significantly among those texts frequently adopted in schools, there were translations from Italian (such as Parravicini's Juanito and Fornari's La Buena Juanita) and French works (including Fenelon's Las aventuras de Telemaco). Original works were Flora, o la educación de una niña (1881) and Escenas de familia (1891) by Pilar Pascual de Sanjuan, and the encyclopedic Carlos (1898) by Francisco Pi y Arsuaga. There were also parodic works such as Las aventuras de Nono (1905) by Jean Grave.

In early modern France the most widespread product was the ABC, entitled La croix de par Dieu or la croisette because of the cross on the first page. It includes the alphabet,

\footnotetext{
${ }^{13}$ En Liden Catechismus, eller Christelige Lardom: gantske nyttelig for unge Folck och Børn (Copenhagen 1574), Copenhagen, the Royal Library, shelfmark: LN $10918^{\circ}$ (fot).

${ }^{14}$ C. Appel, 'Bøger i 1700-tallets nordjyske landsbyskoler', 'in: Fund og Forskning, 51 (2012), pp. 233-59.

15 'Lo que los curas o aquellos a quien ellos lo encomendare(n) son obligados por las constituciones synondales a enseñar a los niños todos los domingos después de bísperas'. Translation by Miriam Borham Puyal.

${ }^{16} \mathrm{~V}$. Infantes, De las primeras letras: cartillas españolas para enseñar a leer de los ss. XV y XVI (Salamanca 1998), p. 36; A. Castillo Gómez, 'Apprendere a leggere e a scrivere nella Spagna della prima età moderna', in: Maestri e pratiche educative dalla Riforma alla Rivoluzione francese. Contributi per una storia della didattica, ed. M. Ferrari \& M. Morandi (Pavia 2020), forthcoming.

${ }^{17}$ L. Resines, Historia de la catequesis en España (Madrid 1995), p. 46.

${ }^{18}$ J. García Padrino, Libros y literatura para niños en la España contemporánea (Madrid 1992).
} 
printed in large characters, some syllables separated by a space or a dash to facilitate reading, and a few prayers. ${ }^{19}$ Other tools for practising reading, although they were not primarily addressed to children or schools before the eighteenth century, were psalters and books of hours. From the 1650s onwards, Catholic catechisms specifically addressed to children, called catéchismes d'enfants, were available in two versions: the catéchisme élémentaire, for children 3-4 years old and to be used in families (16 to 64 pages), and another for children in school-age heading to their First Communion (100 to 200 pages). ${ }^{20}$

It is only from the end of the seventeenth century, after the multiplication of village schools managed by bishops, and especially in the eighteenth century, that educational printed products became commonplace in France. The spread of schools in the Northern part of the country and the birth of the so-called 'Bibliothèque bleue' significantly influenced the increase of a production specifically addressed to children. Not by chance do we find in eighteenth-century printers' catalogues a special section specifically listing books-to-be-usedin-schools. Popular books for educational purposes were printed either by small provincial printers or in large peddling literature centres, which developed from the seventeenth century onwards in Troyes (in Champagne), Rouen (in Normandy), Limoges (Limousin). In Troyes, the 1789 inventory of the Garnier family's assets shows that about $5 \%$ of the production comprised $\mathrm{ABCs}$, primers, conduct books and arithmetic, and $12.7 \%$ consisted of books for religious education, partly for children. ${ }^{21}$ The catalogue of the 'boutique de la veuve Oudot', the bookshop that distributed in Paris the peddling books of the Oudot printers (from Troyes), was the first devoted to school items (c.1720). These books were then sold in town and countryside by peddlers, often available in village shops. In Lorraine, fiscal sources and bankruptcy inventories of the end of the eighteenth century suggest that every fourth village had a haberdasher and that some of them, alongside paper and pencils, sold books. ${ }^{22}$ The range was limited (mostly ABC books, psalters and books of hours), but they were all cheap and sold in quantity.

Further evidence of the books used by children emerges from the records of seizures made in clandestine schools (schools run by teachers without the authorisation of the bishop or the teachers' guilds). Domestic inventories are, unfortunately, of little use in this respect. As books given to children were by nature inexpensive and not highly valued, they were often disregarded when it came to compiling inventories. Nevertheless, we know that working-class children owned psalters and books of hours in the eighteenth century because we have records of such books being found on them. Officials discovered such books on small corpses lying by the roadside or in the pockets of children caught pilfering or left to drive their herds in the fields. Sometimes rural officers took these books as security to force children to comply with court orders. ${ }^{23}$

\footnotetext{
${ }^{19}$ D. Julia, 'Livres de classe et usages pédagogiques', in: Histoire de l'édition française, ed. R. Chartier \& H.-J. Martin, vol. 2: Le livre triomphant, 1660-1830 (Paris 1984). See also J. Hébrard, 'Les livres scolaires de la Bibliothèque bleue: archaïsme ou modernité?', in: Colportage et lecture populaire. Imprimés de large circulation en Europe, XVIe-XIXe siècles, ed. R. Chartier \& H.-J. Lüsebrink (Paris 1996), pp. 109-136. ${ }^{20}$ A. Monaque, Catéchismes diocésains de la France d'Ancien Régime conservés dans les bibliothèques françaises (Paris 2002).

${ }^{21}$ H.-J. Martin, 'Culture écrite et culture orale, culture savante et culture populaire dans la France d'Ancien Régime', in: Journal des savants 3 (1975), pp. 225-82.

22 J. Villain 'La boutique et les différentiels intra-régionaux de l'offre: le cas de la Lorraine à la fin du xviiie siècle', in: Retail Trade. Supply and demand in the formal and informal economy from the 13th to the 18th century. Selezione di ricerche (Florence 2015), pp. 185-212.

${ }^{23}$ F. Bayard, 'Au cœur de l'intime : les poches des cadavres. Lyon, Lyonnais, Beaujolais, XVIIe-XVIIIe siècle', in: Bulletin du centre d'histoire économique et sociale de la région lyonnaise, 2 (1989), pp. 5-41; M. Philippe, Une religion des livres (1640-1850) (Paris 2003).
} 
The use in school of chivalric poems and other non-educational literature is attested by the attempt of the bishop of Angers in 1678 to ban from schools 'tales, romances and all the secular books used to teach how to read'. ${ }^{24}$ There is little solid evidence of their use in schools, however, and we might doubt how widespread the practice was. There is no mention of them in the bishops' pastoral visits reports, for instance, in spite of the fact that the bishops were deeply worried about the use of Protestant and Jansenist books in schools. Nevertheless, secular books were used by self-teaching readers, such as the Lorrainese shepherd Valentin Jamerey-Duval, future librarian of the Grand Duchy of Tuscany, who taught himself to read by finding in the 'Bibliothèques bleue's booklets some texts that he already knew by heart thanks to collective oral reading practices (in particular Aesop's Fables and French chansons de geste). ${ }^{25}$

At the beginning of the eighteenth century printers started to explicitly address a few works to children, aimed at providing reading material to children in school age, such as the 'historical catechisms'. ${ }^{26}$ For example, they added into ABCs some 'prayers to recite before going to school', or replicated in the structure of the booklet the schools' practice of having morning prayers in Latin and evening prayers in French.

Alike in France the creation of a market for children in Italy was a slow process.

Popular books were certainly used and read by children and young people in the early modern period but, unlike in other countries, these texts were never specifically designed for young readers until the beginning of the nineteenth century. ${ }^{27}$ The reasons for this 'delay' are manifold and still work needs to be done, but the political fragmentation of the country before 1861 heavily contributed to limit the mass education seen in other countries.

The first didactic tool used in Italy was the alphabet written or painted on a parchment or paper sheet pasted on a wooden table to be fixed on the wall. A teacher would point to each letter while students had to recognise and recite them. There were also small tables with drawn letters for personal use at home and school. Hornbooks, called in Italy tavoletta, carta crocesanta or santacroce, were probably the only tools specifically thought fit for easily handling by children in the early modern period. ${ }^{28}$ Generations of Italian children learned their first words or syllables on these tools even before the coming of the book. For example, in Pietro da Talada's painting 'Madonna col Bambino' ['Madonna with the child'] in the Church Santa Maria di Capraia in Pieve Fosciana (c.1460), Jesus is depicted holding a hornbook with the alphabet and a few syllables. Hornbooks were often sold on the street by peddlers and other itinerant sellers among other chapbooks and goods. ${ }^{29}$ In the image of a

\footnotetext{
${ }^{24}$ 'Les livres de fables, les romans et toutes sortes de livres prophanes dont on se sert pour commencer à leur [les élèves] apprendre à lire'. H. Blom, 'Vieux romans' et 'Grand Siècle'; éditions et réceptions de la littérature chevaleresque médiévale dans la France du dix-septième siècle (Utrecht 2012). Translation by Emmanuelle Chapron. See also Hébrard, art. cit. (n. 19).

${ }^{25}$ V. Jamerey-Duval, Mémoires. Enfance et éducation d'un paysan au XVIIIe siècle, ed. J.-M. Goulemot (Paris 1996).

${ }^{26}$ Histoires abrégées de l'Ancien Testament [...] imprimées en faveur de la jeunesse chrétienne (Troyes [1728]), Marseille, Centre de documentation et de ressources du Musée des civilisation de l'Europe et de la Méditerranée, shelfmark: 1R 1150.

${ }^{27}$ Our sincere thanks to Piero Lucchi, Mario Infelise, Patrizia Zamperlin, Donatella Lombello, Silvia Carraro, Fabio Targhetta who contributed to this part of the article.

${ }^{28} \mathrm{P}$. Lucchi, 'La Santacroce, il salterio e il babuino: libri per imparare a leggere nel primo secolo della stampa', in: Quaderni storici, 38 (1978), pp. 593-630; Id., 'Leggere, scrivere e abbaco: l'istruzione elementare agli inizi dell'età moderna', in: Scienze credenze occulte livelli di cultura. Convegno internazionale di Studi Firenze, 2630 giugno 1980 (Florence 1982), pp. 101-119; Id., 'La prima istruzione. Idee, metodi, libri', in: Il catechismo e la grammatica, ed. G.P. Brizzi, vol. 1 (Bologna 1985), pp. 25-81; P.F. Grendler, Schooling in Renaissance Italy: Literacy and Learning, 1300-1600 (Baltimore 1991); A. Bartoli Langeli, M. Infelise 'Il libro manoscritto e a stampa', in: L'italiano nelle regioni. Storia della lingua italiana, ed. F. Bruni, vol. 2 (Milan 1996), pp. 655-708. ${ }^{29}$ See also Lucchi, art. cit. (n. 28: 1978), pp. 596-7.
} 
'cestariolo' (a seller with a basket) engraved by Giuseppe Maria Mitelli in 1647 and inspired by a previous drawing by Annibale Carracci, small boards hang from his basket full of books. The caption reads 'tavolette e libri per li putti', meaning 'tablets (or hornbooks) and books for children' ${ }^{30}$ Children or adults could learn the alphabet also while reading or reciting verses in which the first verse of each terzina or stanza started with a letter of the alphabet, such as in Lo alphabeto delli villani, printed in Venice after 1542.

After learning the alphabet and possibly a few syllables, children would learn to read and recite in Latin the main Christian prayers. For this purpose there was the salterio, a small booklet which started with a cross (the signum crucis) followed by the alphabet and the main prayers in Latin, a tool very similar to the Spanish cartilla, the French croisette, and the English simplified version of a psalter. [Fig. 1, 2, 3] According to Piero Lucchi, there was another tool between the salterio and the first grammar of which little is known: the syllabary. Teachers would prepare brief syllabaries for their students on ephemeral supports, such as wax tablets or paper sheets which, due to their nature, survive only in exceptional cases. ${ }^{31}$ In the sixteenth century there were a few initiatives of printing this object in the Venetian Republic. Already at the beginning of the century, the well-known scholar-printer Aldus Manutius included a small syllabary in his Institutionum grammaticarum libri quatuor (Venice 1508) between the Latin prayers and the proper Latin grammar. At least another two examples are documented in the 1550s. The privileges granted to these publications for ten years may have limited the spread of the new syllabic system in Venice. Some sporadic evidence of the existence of this tool refers to this as the 'Babuino', probably from the first syllables 'Ba-be-bi-bo-bu' or perhaps echoing the name of an Arabic syllabary. ${ }^{32}$ The Babuino is attested mainly in the sixteenth century in Venice and other Italian cities (such as Ferrara, Cremona, Milano). In the following centuries, this name almost disappeared, although syllables were included in a few publications for learning how to read. Perhaps conservative teachers and grammarians didn't completely accept the syllabic method, considering it crude. Another explanation could be that wax tables and paper sheets continued to be used for this purpose in school. ${ }^{33}$ It needs to be noticed that the Babuino wasn't exclusively an educational tool for children. For example, in a 1505 Venetian edition of the Babuino children are not mentioned at all. On the last page, the printer more generally, and wryly, informed buyers that they could find the syllables of almost all the languages in the world in this book. ${ }^{34}$

After the alphabet, the syllabary, and the salterio, Italian children generally learned to read with the help of the Donato al senno (a grammar book), the Fior di virtù [Selection of virtues] and chivalric poems also called 'books of battle' ('libri di battaglia'), such as Orlando furioso and Buovo d'Antona. This becomes clear from the comparison between the declarations on the books used in schools released by the Venetian teachers in 1587-88 and the list of the cheap books adopted in schools written by printers and booksellers in $1670 .{ }^{35}$

\footnotetext{
${ }^{30}$ See A. Bertarelli, 'I gridi di piazza ed i mestieri ambulanti italiani dal secolo XVI al XX', in: Il libro e la stampa, 1.3 (1907), p. 16.

${ }^{31}$ P. Lucchi, 'Nuove ricerche sul Babuino. L'uso del sillabario per insegnare a leggere e scrivere a tutti in lingua volgare (sec. XV-XVI)', in: Lesen und Schreiben in Europa, 1500-1900. Vergleichende Perspektiven, ed. A. Messerli \& R. Chartier (Basel 2000), pp. 201-34.

${ }^{32}$ P. Lucchi, 'Un trattato di crittografia del Cinquecento: Le zifre di Agostino Amadi', in: Matematica e cultura, ed. M. Emmer (Milan 2004), pp. 39-49.

${ }^{33}$ See Lucchi, op. cit. (n. 3), pp. 233-4.

34 'Avisandote compratore che troverai in esso squasi tutte le sillabe de tutte le lingue del mondo', colophon: Questo sie vno libreto vtilissimo a chi non sapesse littere de imparare presto elqual se chiama Babuino. (Venice, G.B. Sessa, 1505); EDIT16: CNCE 78555. Translation by Laura Carnelos.

${ }^{35}$ V. Baldo, Alunni, maestri e scuole in Venezia alla fine del XVI secolo (Como 1977). About the list see L. Carnelos, 'Con libri alla mano'. Editoria di larga diffusione a Venezia tra '6 e '700 (Milan 2012), pp. 30-32.
} 
The Donato al senno was the first Latin grammar children read and it was based on the Ars minor by Elio Donato (fourth century), while the Fior di virtù was the first book in vernacular used in schools and one of the longest-lasting bestsellers printed in Italy from the fifteenth to the nineteenth centuries. Written probably at the beginning of the fourteenth century, the latter was composed of chapters illustrating vices and virtues with exempla. ${ }^{36}$

Although surely handled by children, these books were targeted at a wider audience. Also other publications which one can think specifically destined to young people, such as the so-called Babuino or the Abaco, were not addressed exclusively to them. On the title page of the Libretto di abaco, the first books for learning how to count, one can read 'useful for everyone who wants to learn without a teacher'. ${ }^{37}$

Similarly to what has been already attested for France, increasing attention to children and young people emerged in Italy in the late eighteenth century when, in some areas of the peninsula, some attempts to enforce mass education were made. Stimulated by enlightened ideas, this change was prompted by the expulsions of the Jesuits (starting from the 1760s) and their suppression. Although various Italian states felt the need for new projects for implementing and extending the education system also to lower classes, ${ }^{38}$ the political instability of these fragmented states, together with serious difficulties in practical aspects for enforcing mass education, made such measures almost ineffective until the unification in 1861. At that time, literacy rates were still very low and were to increase extremey slowly. ${ }^{39}$ As a consequence, it was not until the late nineteenth century that the design of books noticeably changed so as to make them more obviously intended for the emerging audience of children from different social classes. A few signs of this new market started to be visible from the second half of the eighteenth century, when the words fanciulli, fanciulle, giovani, putte, putti (all terms for identifying young people) appeared more often on the title pages of cheap books, as is demonstrated by analysis of the sale catalogues of the Remondini - the most important publisher of cheap print in Italy, active from the $1650 \mathrm{~s}$ to the $1860 \mathrm{~s} .{ }^{40}$ Abachi, salteri, Christian doctrines, grammars, books of proverbs began to be addressed more specifically to children and young adults, such as in the Fior di virtù istoriato utilissimo a fanciulli e ad ogni fedel cristiano (Bassano, s.d.) and in Pietro Vanni, Ristretto del catechismo in pratica, accomodato alla capacità de' giovanetti (Venice and Bassano, s.d.), an abridged catechism for children. ${ }^{41}$ At the same time, probably influenced by the French production, also some moral tales for middle-class children started to be printed, for example Favole ad uso dei fanciulli [Fables for Children] by Giuseppe Manzoni (1761), Novelle piacevoli [Pleasant Tales] by Pier Domenico Sorese (1762), the Novelle morali [Moral Tales] by Francesco Soave (1782) and the Italian translations of the Magasin des enfants by Madame Leprince de Beaumont. Although the aim of these publications was still mainly

\footnotetext{
${ }^{36}$ P.F. Grendler, 'Come Zuanne imparò a leggere: scolari e testi in volgare nelle scuole veneziane del '500', in: Scienze credenze occulte livelli di cultura. Convegno Internazionale di Studi (Firenze, 26-30 giugno 1980) (Florence 1982), pp. 87-99. More extensively Id., op. cit. (n. 28) and P.F. Gehl, Humanism for Sale. Making and Marketing Schoolbooks in Italy, 1450-165, available at https://www.humanismforsale.org.

37 'Utilissimo a cadauno per imparare per se stesso senza maestro'. Libretto di abaco nouamente stampato: composto per lo eccellente maestro Ioanne Francisco dal Sole (Venice, F. Bindoni \& M. Pasini, 1526); EDIT16: CNCE 39923. Translation by Laura Carnelos.

${ }^{38}$ For a synthetic account cf. G. Genovesi, Storia della scuola in Italia dal Settecento ad oggi (Rome-Bari $\left.2005^{2}\right)$, pp. 18-27.

${ }^{39}$ From $78 \%$ of illiterates against the whole population in 1861 the number descreased to $56 \%$ in 1901 . Cf. ibid., p. 246.

${ }^{40}$ For two centuries the Remondini sold unbound at a fixed price per ream the most popular Italian books, therefore called 'books by ream' [libri da risma]. See L. Carnelos, I libri da risma. Catalogo delle edizioni Remondini a larga diffusione (1650-1850) (Milan 2008).

${ }^{41}$ Children or young adults could be mentioned on the title page or inside the text. See Carnelos, op. cit. (n. 40), nn. 199b, 583a, 161a.
} 
educational and strictly linked to the school and the church environments, the market was definitely embracing children and young people as new potential customers.

\section{Pleasant readings for children}

Although the boundaries that separate recreational and educational purposes are blurred, we can assume that a large variety of popular print was read for enjoyment. In this part of the article we will focus on cheap printed matter specifically designed to give children pleasure, explaining how this market took shape in various European countries and absorbed new revolutionary techniques, such as the introduction of colour in the printing industry.

Sporadic cases of popular materials specifically printed for the entertainment of children (almanacs, penny prints, chapbooks, and some kinds of books of secrets that contained also jokes and riddles) are attested in Northern countries before the eighteenth century. Paratexts, including title pages, give evidence of this 'early' targetting of young readers, as in Den sack der consten, the book of secrets mentioned in the opening of this article. This also happens in almanacs printed in the following century, such as the Youth's entertaining and instructive calendar published in London at least from 1750 (although this was not an especially cheap publication). ${ }^{42}$ In these countries popular literature explicitly addressed to children began to be an established business in the eighteenth century, followed a century later in Mediterranean countries. The creation of a market for children is connected to many factors, including the development of different educational systems, social and cultural changes brought about by the Enlightenment, and later the Romantic interest for folk tales, and thence in fairy tales for children. Changes in printing technologies and the booktrade were important too in forming transnational discrepancies because successful ventures in printing for children needed to be founded on an ability to print cheaply and distribute widely, and since cheap print increasingly came to rely on attractive typography and on the presence of coloured pictures.

Indeed, since illustrations were such a fundamental element of children's cheap print, and since colour came to be a crucial part of this appeal, it is worth dwelling on this history of this transformation. Illustrations had of course been an important element of printed books, and especially popular literature, since the very earliest years of printing. Until the midnineteenth century, however, European cheap printing had almost always been in black and white. Colour could be applied by hand (brush or stencil) or through the combined use of stencils and printing presses (as documented in the wallpaper industry). ${ }^{43}$ When handcoloured, the book price increased by between a third and a half the original price.

Sometimes, colour could be added during the printing process, through the superimposition of multiple matrices, selective inking procedures, or a mixture of the two, but the printed results were enormously expensive and are, with a very few exceptions, unrecorded in children's publishing. Therefore, cheaply printed materials that were read across Europe by children were usually poorly illustrated. This changed during the mid- and second half of the nineteenth century, when new techniques allowed cheaper books in colour to circulate widely, first in Northern Europe and then in the Mediterranean regions. ${ }^{44}$ Chromo-relief was

\footnotetext{
${ }^{42}$ Youth's Entertaining and Instructive Calendar for [...] 1750; containing an explanation of all the feasts and fasts appointed to be observ'd in the Liturgy of the Church of England, and all other remarkable days [...]. (London [1749])Another issue, published in 1789, is preserved at the National Art Library London.

${ }^{43}$ See 'The description of stencilling by Gilles Filleau des Billettes: transcription and translation', in: Typography papers 9, ed. E. Kindel \& P. Luna (London 2013), pp. 66-86.

${ }^{44}$ On George Baxter's method see M.E. Mitzman, George Baxter and the Baxter prints (David \& Charles, 1978); on chromolithography see M. Twyman, A History of Chromolithography: Printed Colour for All (London 2013).
} 
the most common method of printing for a cheap market in Britain until the early twentieth century, whereas chromolithography had an enormous success in Germany, France and the Netherlands, as the ideal technique to obtain images on large sheets.

Bearing in mind these technical changes, we look first at Britain where much has been made of the 'invention of children's literature' in the middle of the eighteenth century. Most scholars still rely on the definition of children's literature proposed by F.J. Harvey Darton (in the 1930s): 'printed works produced ostensibly to give children spontaneous pleasure and not primarily to teach them.' According to this definition, major developments occurred in the 1740s, when enterprising publishers, mostly in London, began to produce handsome, clever books aimed directly at young readers, and presenting their content in attractive ways. ${ }^{45}$ The prices charged for this material were not high - sometimes as low as a penny. And yet this was probably not really popular print: it was aimed at a respectable, bourgeois audience, and sold in bookshops rather than in everything shops or by itinerant peddlers. Similarly, these books were generally well-produced, with clear print set in wide margins, numerous images (usually wood blocks, but sometimes copperplates), attractive bindings and even sometimes gilt edges. ${ }^{46}$

What these books proved, however, was that there was a market for titles aimed directly at children. It was not long, therefore, before cheaper, more ephemeral versions of children's books started to appear - perhaps from as early as the 1750s, although low survival rates make it difficult to determine with precision. These titles constitute exactly what we are looking for: children's popular print 'produced ostensibly to give children spontaneous pleasure' (in Darton's phrase). Certainly by the 1770s, cheap, low-quality titles were being published, in London, but also extensively in the provinces - probably to be circulated by chapmen as well as to be sold in shops, and indeed they are often referred to as 'chapbooks' (although these 'children's chapbooks' constitute a specific sub-genre). In terms of format, these titles were typically duodecimo or smaller, in 8,24 or 36 pages (sometimes longer), and often used old woodblocks, sometimes re-employed rather promiscuously, to be hand- or dab-coloured. They were published without boards, but quite often with attractive wrappers, which frequently identified them as part of a series. Content varied, but could include, even within the same series, traditional tales (taken from romance-literature like Guy of Warwick, King Arthur, Robin Hood); fairy tales and Arabian Nights stories; travel narratives; moral tales; songs; puzzle books; jest books; and so on. They could also contain more evidently instructional material too (alphabets, catechisms, 'Reading Made Easy'). After all, there was little distinction between recreational and didactic content. Some of the most intriguing examples are radically abridged novels, such as Defoe's Robinson Crusoe (or later Campe's Robinson der Jüngere) or even Fielding's Tom Jones. ${ }^{47}$ Such books were commonplace by 1800 in Britain and remained in circulation long into the nineteenth century. They were probably supplanted only when new, mechanised printing methods radically changed the bookhistorical landscape.

Intriguingly, this popular children's literature generally maintained a deliberate and overt decency in terms of its content. However cheap, flimsy, and contemptible the format, publishers strove to provide texts that were far from coarse - maintaining a strong moral, didactic and respectable agenda. Titles that can be identified as 'children's chapbooks', for example, might offer chivalric stories that, in previous generations, had been thought unsuitable for children, but were now presented as moral or educational, with lessons in

\footnotetext{
${ }^{45}$ A Little Pretty Pocket-Book, Intended for the Instruction and Amusement of Little Master Tommy, and Pretty Miss Polly, published in 1744 by John Newbery in London, is generally considered the first children's book in English.

${ }^{46}$ Cf. M.O. Grenby, The Child Reader, 1700-1840 (Cambridge 2011).

${ }^{47}$ Cf. Grenby, art. cit. (n. 4); Cooper, art. cit. (n. 4); Bold, art. cit. (n. 4).
} 
morality, or antiquarianism, appended. Later, in the early nineteenth century, evangelicals appropriated the format for their own purposes - providing the public with nicely-produced, well-illustrated and entertaining books (stories, or verse) that retailed a clear religious message. These were so heavily subsidised that they sold for very low prices, or in fact were often given away by religious societies or philanthropic individuals. ${ }^{48}$

Although as things stand we have only fragmentary information, we would like to include some examples from the geographical areas that is now referred to as the Netherlands, since they show an early emergence of cheap print for children. Besides moral tracts, fables and romances were specifically printed for children and used in schools as early as the seventeenth century. ${ }^{49} \mathrm{We}$ are aware that further insight into the existing literature on Dutch children's books will allow a better understanding of cheap print for children, ${ }^{50}$ yet we would like here to single out some interesting cases.

In the eighteenth century, two books identifying themselves as 'almanacs' were addressed specifically to a child audience. These were Nieuwe Lorre Kinder Almanach, published in The Hague in 1760, whose title makes clear its intended readership, and St. Nicolaas Almanach (also printed in The Hague by the same printshop over the period 17601800), which was commonly advertised as suitable for children. As far as their materiality is concerned, they can be considered popular products: their woodcuts are reused from other printed products and their price, six 'stuivers', is comparable with other cheap print.

Nonetheless, although widely illustrated with woodcuts intended for attracting young readers, the captions seem not always adapted for the allegedly targeted audience: some texts included in the almanac were educational, but they addressed parents more than children. Moreover some more playful texts seem to have been targeting a wider audience: it has been pointed out that one verse published in the almanac has an erotic meaning. Futhermore the almanac part was not at all adapted to a young reader, containing exactly the same kind of information that one would expect in an almanac for a general audience. ${ }^{51}$ All this seems to suggest that Dutch publishers were aware of the potential of children as an audience and experimented with texts and genres creating interesting hybrids on which further research needs to be conducted.

A third relevant typology that had wide success in the Dutch-speaking area is represented by centsprenten, or penny prints: illustrated broadsides narrating stories through woodcuts and rhyming captions. Although not specifically intended for children, at least originally, their layout was undoubtedly attractive for them, and in fact they proved successful in different European areas, as argued by Gomis and Salman. ${ }^{52}$

At this stage also information on Scandinavia is fragmentary. However, it seems that early examples of cheap entertaining print existed in Denmark as well, such as fables, romances and chapbooks, that might certainly have interested a young audience, but there is

\footnotetext{
${ }^{48}$ Cf. From the Dairyman's Daughter to Worrals of the WAAF: The RTS, Lutterworth Press and Children's Literature, ed. D. Butts \& P. Garret (Cambridge 2006).

${ }^{49}$ Cf. Salman, op. cit. (n. 4).

${ }^{50}$ Recent scolarship on Dutch children's literature is rich, and although not specifically centred on cheap publications, it offers useful insights. Also in the Dutch-speaking areabridging research on children's literature with scholarship on popular print would provide a deeper knowledge of cheap print for children. Cf. ibid.; P.J. Buijnsters \& L. Buijnsters-Smets, Lust en leering. Geschiedenis van het Nederlandse kinderboek in de negentiende eeuw (Zwolle 2001); Eid., Papertoys. Speelprenten en papieren speelgoed in Nederland (16401920) (Zwolle 2005); F. Dietz, 'The Shaping of Young Consumers in Early Modern Book-Objects. Managing Affects and Markets by Books for Youths'. In: Early Modern Knowledge Societies as Affective Economies, ed. I. Leemans \& A. Goldgar (forthcoming).

${ }^{51}$ Cf. J. Salman, 'Die ze niet hebben wil mag het laaten'. Kinderalmanakken in de achttiende eeuw', in: Literatuur, 17 (2000), pp. 76-84. .

${ }^{52}$ Cf. Gomis \& Salman, Tall Tales for a Mass Audience, infra.
} 
no clear evidence that they were addressed to children. On the contrary, moral and religious tracts, whose purpose was not uniquely entertaining, were the most widespread nonprimarily-educational products specifically printed for children prior to the late eighteenth century. After that turning point, fables for children were published in anthologies and between the 1770s and 1800 broadsheets and chapbooks for children appeared on the market. There is still little evidence of this, but new research is being conducted. ${ }^{53}$

Regarding the development of German children's literature, scholars have emphasised the work of the so-called 'philanthropists', strongly influenced by Rousseau's thoughts on education, from around 1770s. Although this new German children's literature was intended for children in the middle and upper classes, this work had impact on popular literature for children. From the last years of the eighteenth century for example, abridged versions of Joachim Heinrich Campe's Robinson der Jüngere were published in Germany, and indeed circulated widely around northern Europe. British chapbook editions of Defoe's novel have been analysed, ${ }^{54}$ but still much needs to be done on the extremely wide range of transnational adaptations and abridgments based on Campe's rewriting, or at least on those inspired by educational aims. One striking example is the 1804 Verkorte geschiedenis van Robinson Crusoe [Abridged story of Robinson Crusoe], a Dutch adaptation by a teacher from Zutphen, Mattheus van Oort, specifically intended for the use in schools. ${ }^{55}$ Similarly to many schoolbooks of that time, such volumes, although affordable by large middle-class audiences, cannot always be surely ascribed to cheap print, due to a more refined appearance. Further research is needed to assess their status within the publishing market, as well as their actual transnationality, but the low survival rates of cheap editions have often discouraged scholars. ${ }^{56}$

The speed with which children's books spread around Europe in the later eighteenth century is remarkable. Works by Campe, Friedrich Eberhard von Rochow (Der Kinderfreund, 1776), Arnaud Berquin (L'Ami des enfants, 1780), Jeanne-Marie Leprince de Beaumont (Magasin des enfants, 1756-57), and others would have been known among the middle- and upper-class children of many northern European countries, either in high-quality, authorised editions, through pirated translations, or indeed in the original language (in France, for example, English and German versions of these titles were used in the language classes in 'collèges', the first level of secondary education). ${ }^{57}$ It was inevitable that these works would be abridged and published in cheaper editions. The earliest French example of an abridgment of Defoe's Robinson Crusoe, for instance, dates to 1810, adapted by Henri Lemaire and issued by the Catholic publisher Ardant. It was followed by cheap versions issued by traditional popular publishers - that is to say, those companies renowned for publishing the so-called 'Bibliothèque bleue', as for instance Les principales aventures de Robinson Crusoé, printed in Rouen by Lecrène-Labbey in 1812 [Fig. 4 and 5].

As already mentioned, in some southern countries the late arrival of mass schooling and the consequent low literacy rates slowed down the development of books for children, which seems to become a separate business only in the late nineteenth century. In Spain romanticism and pre-realism, with its focus on popular folklore, also influenced authors and

\footnotetext{
${ }^{53}$ We are grateful to Charlotte Appel and Nina Christensen for sharing with us the first results of their project, art. cit. (n. 5).

${ }^{54}$ The most recent contribution is A. O'Malley, Children's Literature, Popular Culture, and Robinson Crusoe (London 2012), pp. 76-101.

${ }^{55}$ Information drawn from a review in Algemeene konst- en letter-bode voor het jaar 1805 (Haarlem 1805), p. 346.

56 An exception is S. Parlevliet, Meesterwerken met ezelsoren. Bewerkingen van literaire klassiekers voor kinderen 1850-1950 (Hilversum 2009).

${ }^{57}$ E. Chapron, 'Comment Robinson Crusoé est entré au collège. Carrières littéraires et fabrique d'un classique au XVIII' siècle', in: Revue historique, t. 680, 2016, pp. 763-84
} 
publishers ${ }^{58}$ leading to a wider range of publications available, initially, mainly for schools. Being based on the 'education with delight' principle, such books were also read for pleasure. As already argued, they were more refined than traditional early modern cheap print but the evolution of printing techniques together with socio-economic changes made them available more widely in the late modern society.

Something similar happened in Italy, where national mass education, in force from 1861, acted as a watershed. However, from the early nineteenth century, religious publishers played an important role in producing and distributing the first cheap books specifically for children, mainly moral tales and adaptations of hagiographies. ${ }^{59}$ Not by chance one of the first best-sellers was the aforementioned Novelle morali by Father Francesco Soave, aimed at providing both reading practice and moral instruction. The author, a religious educator, was responsible for shaping the system of free primary schools in Milan (1780s). As already seen in Spain, such titles were not exclusively conceived for use at school, but could also be read for pleasure. They circulated widely, although they could seem more refined than their predecessors in other European countries. Interestingly, works by the Bavarian Catholic Priest Christoph von Schmid, famous for Ostereier [Easter Eggs] (1816), were translated into Italian from the 1820s and would often be more successful than the Italian translation of Campe's Robinson der Jüngere. The story of the shipwrecked Englishman became instead a classic of Italian children's literature through Johann David Wyss's Schweizerischer Robinson [Swiss Family Robinson] (1804), usually translated into Italian from French, firstly in highly refined, but later in popular, editions. French influence was particularly relevant in the Italian culture and publishing market, and therefore other European best-sellers entered the Italian publishing market through France. For instance the name of Rochow was rarely mentioned by educators, but his texts were read in Italy through the many translations of L'ami des enfants by Berquin (from 1795). ${ }^{60}$

Although the category of children's literature emerged later in Italy than in other European nations, it is clear that Italian children would have gained amusement from printed images long before the nineteenth century, notably through products like playing cards and board games. These were produced in large quantities by important early modern chapbook publishers such as the Remondini (Venice), the Soliani (Modena) and the Marescandoli (Lucca). Such cards and games were not specifically intended for the young, but they may have been the only printed materials that some children handled for fun.

Publications, consisting of printed images with brief printed captions and typically printed on one side only of a single sheet, had a long tradition in other countries, in particular Spain, Britain and, as mentioned earlier, the Low Countries, where they were termed (respectively) aleluyas, catchpenny prints or penny prints, and centsprenten. Whereas they were originally intended for a mixed-age audience, from the later eighteenth century they started to be specifically addressed to children, as discussed by Gomis and Salman. ${ }^{61}$ It is important to highlight that in Spain aleluyas represent indeed the earliest, and for some decades sole, evidence of recreational cheaply printed products that might have been used by children. This is corroborated by the presence of the words 'children' or 'childhood' in some early examples. An example is Jochs de l'Infanteça (1674), which describes games played by

\footnotetext{
${ }^{58}$ Cf. C. Bravo Villasante, Historia de la literatura infantil española (Madrid 1969).

${ }^{59}$ See the case of Giacomo Agnelli in E. Marazzi, Libri per diventare italiani. L'editoria per la scuola a Milano nel secondo Ottocento (Milan 2014), pp. 144-60.

${ }^{60}$ On foreign, especially French influences see S. Valeri, 'La fortuna della letteratura francese per l'infanzia nella seconda metà del Settecento', in: History of Education and Children's Literature, 1 (2006), n. 2, pp. 173207; Ead., Libri nuovi scendon l'Alpi (Macerata 2016), pp. 83-128; A. Ascenzi \& R. Sani, Storia e antologia della letteratura per l'infanzia nell'Italia dell'Ottocento, 1 (Milan 2016), pp. 41-75

${ }^{61}$ Gomis \& Salman, art. cit. (n. 52).
} 
children, such as the skipping rope for girls, the bumblebee, how to make toys with cork and feathers. Similarities with aleluyas printed in the following centuries are striking: the same games are illustrated in Juegos de la infancia (1847) and the Lotería moderna para los niños $(1861){ }^{62}$

Like books, such products were usually printed in black and white, hand- or dabcoloured, but the evolution of techniques deeply influenced printed images. As already said, chromolithography had an enormous success in Germany, France and the Netherlands, as the ideal technique to obtain images on large sheets. Indeed, a specific niche in the cheap children's publishing were the penny prints issued by specialised printshops of Neuruppin in Germany (Bilderbogen) and Épinal in France (and, later, in other countries, including, Italy). The widespread model became a 30x40 cm sheet containing twenty images (5 rows with 4 pictures each) with captions that were usually narrations of popular stories, fairy tales, or moral tales, but sometimes also instructional materials (especially visual alphabets) ${ }^{63}$ In some cases, the spreadsheet was folded to form a small booklet, printed and coloured. However, the broadside was the norm. Cheap board games, toy theatres, or even toys were printed on illustrated single sheets: the Pellerin printshop in Épinal started its activity with small soldiers to be cut out after having pasted the sheet on cardboard. As time went by, the same paste-and-cut technique was to be applied by the purchasers of such broadsheets in order to build more complex paper toys, such as reproductions of monuments or even movable figures to be used on a paper theatre stage.

\section{Conclusions}

The outline of transnational cheap print for children sketched here is definitely not comprehensive. For instance, taking into account a wider geographical area will not necessarily lead to the same outcomes. Further investigation into the markets of educational cheap literature should also be undertaken. Was there a separate market for schoolbooks? Were there different distribution circuits? Or did such items follow the paths of popular book trade? ${ }^{64}$

In spite of the work that still remains to be done, it is possible to draw some initial conclusions. First of all, educational works must have represented a substantial part of print culture in the early modern period. This is particularly true for the cheap and popular end of the market. It is difficult to put a figure on it, but surely a great deal of the cheap print flowing from the presses, right across Europe, must have served the demand for teaching. Consequently, since so much of this educational material was either solely or partly for children, we can see how important children were to the cheap print industry. As demonstrated, the market for cheap children's print developed at a different pace in different places. Britain (or at least England), Germany and the Netherlands developed this market quite early. Sometimes, as in the example of Dutch almanacs, it is possible to argue that publishers were aware of children representing a new, profitable audience, but were still experimenting how to address them. France, Spain (with the exception of didactic materials), and particularly Italy were slower to produce titles that were specifically targeted at young readers, even if it is undeniable that children were significant consumers of popular educational print even before they were openly addressed in titlepages and paratexts.

\footnotetext{
${ }^{62}$ J.M. Martínez González, 'Juegos infantiles en los pliegos de aleluyas barceloneses y madrileños de la segunda mitad del siglo XIX. Las loterías', in P. Cerrillo \& C. Sánchez, Presencia del cancionero popular infantil en la lírica hispánica (Cuenca 2013), pp. 385-407.

${ }^{63}$ P. Cerrillo \& J.M. Martínez González, Aleluyas. Juegos y literatura infantil en los pliegos de aleluyas españoles y europeos del siglo XIX (Cuenca 2012).

${ }^{64}$ E. Marazzi, supervised by M.O. Grenby, is carrying out research on this with the project: Children and

Transnational Popular Print 1700-1900 (EU-MSCA grant agreement n. 838161).
} 
With the material that can be called 'recreational' cheap print, there are even more challenges, since less evidence of children reading it is available and there is less pre-existing research at a local and regional level. A history of reading approach will perhaps be of most help in further investigations, since evidence of individual children's book use could allow us to confirm which texts or genres of popular print were particularly used by children: chivalric romances, for instance, or fables. ${ }^{65}$

Printed images also included cheap games and there seems to be a widespread tradition of this kind of products, that might have also been used by children, although it is often difficult to understand if they were the intended audience. However, illustrated broadsides are likely to shed new light on book trade networks in modern Europe: only a small number of families produced and distributed such printed images in each country, but these products can be found in almost all Europe. As suggested by Piero Lucchi, the increase in number and variety of toys, especially in Northern countries, and the role played by toy fairs should be comparatively analysed with the print market to widen the scope of a transnational study on children's recreational material. Also the study of printing techniques in the age of steam press is vital: the full range of the mixed techniques mentioned above is still little understood, as well as their role in the production of children cheap books (including, in some regions, those primarily intended for educational purposes), and toys.

Research is also needed for understanding the development of 'non-cheap' children's literature and its relationship with cheap literature. Did the arrival of more refined and expensive products bring about changes in how cheap print was conceived and distributed? And did cheap print have an influence on more refined children books?

Although much research is needed, this preliminary comparative approach already highlights some features that will need to be taken into account in future analysis. First of all, the transnational nature of cheap print for children. Networks for the production and distribution of cheap print in general were transnational: previous research has shown that the most successful specialised publishers, such as Remondini and Brepols, and later Pellerin from Épinal and the German Bilderbogen printers from Neuruppin, managed to sell their products throughout, and even outside, Europe thanks to different arrangements: networks of booksellers and pedlars, partnerships, and branches abroad. Such publishing houses did produce the genres of cheap print that were addressed to children or used by them, hence they circulated through the same channels. ${ }^{66}$

It is evident that such transnational circulation was not limited to genres and formats: the stories narrated in booklets and broadsides were often the same, and they circulated in different regions in different languages. Schlusemann and Wierzbicka-Trwoga show, in this volume, how some fictional narratives were printed in at least six European languages from the early age of printing until at least the end of the eighteenth century ${ }^{67}$ Moreover, the same works could be adapted for use of different audiences. Gomis and Salman have argued that

\footnotetext{
${ }^{65}$ On this topic cfr. M. Roggero, Le carte piene di sogni. Testi e lettori in età moderna (Bologna 2006); Ead., 'Des enfants et des livres. Remarques sur des souvenirs d'enfance du monde anglo-saxon', in: Études de lettres [Online], 1-2 | 2016, http://journals.openedition.org/edl/878, and 'Un fatras de livres auquel l'enfance s'amuse. Lectures de jeunesse et romans de chevalerie au XVIe siècle', in: Camenulae, 4 (2010), pp. 1-10.

${ }^{66}$ M. Infelise, I Remondini. Stampa e industria nel Veneto del Settecento (Bassano 1990); J. Salman, 'Devotional and Demonic Narratives in Eighteenth- and Nineteenth-Century Dutch Penny Prints', in: Cheap Print and the People: European Perspective on Popular Literature, ed. D. Atkinson \& S. Roud (Newcastle upon Tyne 2019), pp. 121-38; P. Vansummeren, Kinderprenten van Brepols (Turnhout 1996). An example that requires further attention is a set of Épinal broadsides printed in Kansas City, Missouri, possibly resulted from a collaboration between 'the Humoristic Publishing co.' and 'Imagerie d'Épinal'. Cotsen Children's Library, Princeton, shelfmark: French Popular Print 149986 (Box 1). On the transnationality of penny prints see also Gomis \& Salman, art. cit. (n. 52 and Cerrillo \& Martínez González, op. cit (n. 63).

${ }^{67}$ Schlusemann \& Wierzbicka-Trwoga, Narrative Fiction, infra.
} 
illustrated pennyprints contributed to the standardisation of juvenile versions of diverse works, such as folk tales, fairy tales and literary classics. ${ }^{68}$ As previously discussed, children were often readers or listeners of the stories circulating through cheap print, we can hence argue that young readers encountered the same stories (often in similar formats) in different areas of the continent.

Moreover, the transnational nature of cheap print for children is particularly evident in teaching materials, that were issued in strikingly similar forms across Europe and also beyond. ${ }^{69}$ From the late eighteenth century the more widespread production of cheap books to be read for pleasure allows us retrace in it the same transnational nature. This might seem a paradox in a period when literary and printing traditions progressively acquired national features. Nonetheless, as it happened in more refined children books, translating and adapting the works of some successful international authors was a viable solution for publishers keen to offer new cheap products to an emerging audience of young readers from the working and middle class.

Of at least one thing we can surely be confident, however. This is that it can be no exaggeration to say that, without the reliable sales to children (or to adults for children) of books designed for either (or both) educational and recreational purposes, the European print industry could not have thrived and developed as it did.

\footnotetext{
${ }^{68}$ Gomis \& Salman, art. cit. (n. 52).

${ }^{69}$ As highlighted by M.O. Grenby during the conference Books for Children: Transnational Encounters 17501850, Cotsen Children's Library, $31^{\text {st }}$ October- $2^{\text {nd }}$ November, 2019.
} 